\title{
Klasyczna postać naciekającego zrazikowego raka piersi w materiale Krakowskiego Oddziału Centrum Onkologii: obraz kliniczny, wyniki leczenia, czynniki prognostyczne u chorych leczonych w okresie 1980-2005
}

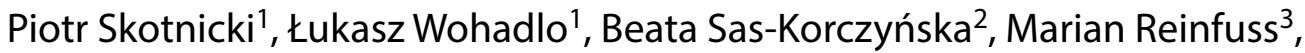 \\ Jerzy W. Mituś ${ }^{4}$, Tomasz Walasek ${ }^{3}$
}

\begin{abstract}
Wstęp. Naciekający zrazikowy (infiltrating lobular carcinoma - ILC) rak piersi stanowi 5\%-10\% wszystkich złośliwych nowotworów piersi. Celem pracy jest przedstawienie charakterystyki kliniczno-patologicznej chorych na klasyczną postać ILC (C-ILC) oraz ocena skuteczności leczenia.

Materiał i metody. Analizą objęto grupę 220 chorych leczonych z powodu C-ILC w latach 1980-2005. W tej grupie dominował I-II stopień zaawansowania klinicznego $(67,7 \%$ chorych). U 172 chorych $(78,2 \%)$ średnica guza nie przekraczała $5 \mathrm{~cm}$, a u 121 chorych (55\%) nie stwierdzono przerzutów w węzłach chłonnych. Badania immunohistochemiczne wykazały obecność ekspresji receptorów: estrogenowego (80,9\%), progesteronowego (72,7\%) i HER2/neu (3,7\%). Zmiany wieloogniskowe w piersi stwierdzono w 14 przypadkach $(6,4 \%)$. U wszystkich chorych przeprowadzono leczenie chirurgiczne: mastektomia ( 189 chorych $-85,9 \%$ ), leczenie oszczędzające (31 chorych - 14,1\%). Adiuwantowe leczenie polegało na stosowaniu: radioterapii ( 141 chorych $-64,1 \%)$, chemioterapii ( 35 chorych $-15,9 \%$ ) oraz horomonoterapii (120 chorych $-54,5 \%)$.

Wyniki. W całej grupie 10-letnie przeżycie bez objawów nowotworu wynosiło $65 \%$. Przeprowadzona wieloczynnikowa analiza wykazała, że niezależnym czynnikiem prognostycznym jest stan mikroskopowy węzłów chłonnych pachowych. W czasie obserwacji stwierdzono rozwój raka w drugiej piersi (19 chorych $-8,6 \%)$, przerzuty odległe wystąpiły u 55 chorych (25\%).

Wnioski. C-ILC wykazuje charakterystyczne cechy kliniczno-patologiczne, a przy zachowaniu właściwej kwalifikacji możliwe jest przeprowadzenie leczenia oszczędzającego. Niezależnym, niekorzystnym czynnikiem prognostycznym jest obecność przerzutów w węzłach chłonnych pachowych.
\end{abstract}

Classical variant of infiltrating lobular breast cancer seen in the Oncology Centre in Krakow: clinical characteristics, results of therapy and prognostic factors in patients treated 1980-2005 Introduction. Infiltrating lobular breast cancer (ILC) accounts for approximately $5-10 \%$ of all breast cancer types. The purpose of this study is to present the clinico-pathological characteristics and treatment results in patients treated for classical variant of ILC (C-ILC).

Material and methods. The analysis was performed in group of 220 patients with C-ILC treated between 1980 and 2005. Stage I or II cancer was found in 67.7\% patients, and in 172 patients (78.2\%) the tumour diameter was lower than $5 \mathrm{~cm}$ (78.2\%), 121 patients (55\%) did not develop lymph node metastases. Immunohistochemical analysis showed estrogen receptor positivity (80.9\%), progesterone receptor positivity (72.7\%) and expression of HER2/neu

${ }^{1}$ Oddział Chirurgiczny Zabiegowy, Szpital im. św. Rafała w Krakowie

${ }^{2}$ Klinika Onkologii, Centrum Onkologii — Instytut im. Marii Skłodowskiej-Curie, Oddział w Krakowie

${ }^{3}$ Zakład Radioterapii, Centrum Onkologii — Instytut im. Marii Skłodowskiej-Curie, Oddział w Krakowie

${ }^{4}$ Klinika Chirurgii Onkologicznej, Centrum Onkologii — Instytut im. Marii Skłodowskiej-Curie, Oddział w Krakowie 
(3.7\%). The multifocal changes were present in 14 cases (6.4\%). All patients received surgical treatment: mastectomy (189-85.9\%) or breast-conserving therapy $(31-14.1 \%)$. The adiuvant treatment consisted of radiotherapy (141 patients - 64.1\%), chemotherapy (35 patients - 15.9\%) and hormonotherapy (120 patients - 54.5\%).

Results. The 10-year disease-free survival rate was $65 \%$. Multivariate analysis showed that an independent statistically significant prognostic factor was microscopic status of axillary lymph nodes. During follow-up the development of breast cancer in the second breast was observed in 19 patients ( $8.6 \%$ ) and 55 patients (25\%) developed distant metastases.

Conclusions. The C-ILC has some specific clinico-pathological characteristics and it is possible to perform breast-conserving treatment in these cases. The negative prognostic factor is the presence of lymph node metastases.

NOWOTWORY Journal of Oncology 2016; 66, 1: 26-34

Słowa kluczowe: zrazikowy rak piersi, przerzuty raka piersi, zaawansowanie raka piersi

Key words: lobular breast cancer, distant metastases of breast cancer, stage of breast cancer

\section{Wstęp}

Naciekający zrazikowy (infiltrating lobular carcinoma — ILC) rak piersi jest drugą pod względem częstości występowania postacią mikroskopową raka piersi i według większości autorów stanowi 5\%-10\% wszystkich złośliwych nowotworów piersi [1-8]. W 1941 roku Forte i Stewart przedstawili charakterystyczne cechy mikroskopowe ILC i wprowadzili do piśmiennictwa nazwę rak zrazikowy [9]; opisany przez nich tzw. „klasyczny" typ ILC stanowi 70\%-85\% przypadków tego nowotworu, co stanowi 3,5\%-8,5\% wszystkich przypadków raka piersi $[10,11]$. W ostatnim 40-leciu opisanych zostało kilka wariantów ILC, do których należą: lita (solid variant) [10-14], pęcherzykowy (alveolar variant) [10-15], cewkowo-zrazikowy (tubulo-lobular variant) [10, 11, $14,16]$, pleomorficzny (pleomorphic variant) [14, 17-20] oraz rzadziej występujące: histiocytoidny (histiocytoid variant) [21], sygnetowato-komórkowy (sygnet ring cell variant) [22], beleczkowy (trabecular variant) [23]. W przypadku, gdy w guzie nowotworowym stwierdza się więcej niż jeden wariant ILC i żaden z nich nie stanowi więcej niż 80\%-85\% obrazu mikroskopowego, autorzy zaliczają taki guz do postaci mieszanej (mixed variant) [11, 12].

Obraz mikroskopowy klasycznej postaci ILC (classical invasive lobular carcinoma - C-ILC) charakteryzuje obecność małych, okrągłych, względnie jednakowych komórek, które nie wykazują cech kohezji i naciekają podścielisko w sposób rozproszony lub tworząc charakterystyczne układy linijne zwane „indiańskimi ścieżkami” (Indian files). Komórki C-ILC tworzą również koncentryczne układy wokół prawidłowych przewodów wyprowadzających na wzór „tarczy strzelniczej" (targetoid pattern); mogą one dodatkowo naciekać podścielisko i tkankę tłuszczową, pobudzając desmoplastyczną reakcję podścieliska. Jądra komórek są małe, owalne lub okrągłe, o zbliżonych rozmiarach, często położone ekscentrycznie. Komórki mają skąpą cytoplazmę i cechują się niewielką liczbą figur podziału [12, 13, 24-26]. Utrata adhezyjności i rozproszenie komórek wynika z faktu, iż komórki tego nowotworu cechuje brak ekspresji adhezyjnej molekuły — kadheryny E [27-32].

Względna rzadkość występowania ILC oraz trudności w jego rozpoznawaniu powodują, że wiele kwestii dotyczących tego nowotworu pozostaje nadal przedmiotem kontrowersji. Dotyczy to w szczególności takich zagadnień, jak: rozległość leczenia operacyjnego (mastektomia vs leczenie oszczędzające - BCT z uwzględnieniem wskazań i przeciwwskazań do każdej z tych metod), rola wycięcia węzła wartowniczego (sentinel lymph node dissection - SLND), ocena wskazań do chemioterapii neoadiuwantowej, wpływ na wyniki leczenia zastosowania chemio- i/lub hormonoterapii adiuwantowej oraz sposób postępowania z drugą piersią. Przedmiotem kontrowersji jest również próba wyjaśnienia istotnych różnic w wynikach leczenia chorych na ILC $w$ różnych ośrodkach i problem występowania różnic w wynikach leczenia pomiędzy chorymi na ILC i naciekającego raka przewodowego (IDC). Powszechnie znana jest charakterystyczna lokalizacja przerzutów odległych; niektóre z nich mają charakter kazuistyczny. W piśmiennictwie brak jest opracowań syntetycznych prezentujących nie tylko nietypową lokalizację tych przerzutów, ale również ich obraz kliniczny, diagnostykę, zastosowane metody leczenia itp. W znacznym stopniu dyskusyjne jest również rokownicze znaczenie poszczególnych wariantów ILC. Różne interpretacje obrazów mikroskopowych, mała liczebność prezentowanych grup chorych, brak stratyfikacji przypadków są przyczyną wielu niejasności. W tej sytuacji istotne wydaje się skoncentrowanie badań nad klasyczną postacią ILC (C-ILC), stanowiącą znakomitą większość przypadków [33-54].

Celem prezentowanych badań jest przedstawienie charakterystyki populacyjno-klinicznej z uwzględnieniem wybranych parametrów histologicznych i biologicznych markerów w grupie chorych na C-ILC oraz ocena skuteczności leczenia tych chorych i analiza niepowodzeń leczenia. 


\section{Materiał i metody}

Analizą objęto grupę 220 chorych na klasyczną postać ILC (C-ILC) leczonych Krakowskim Oddziale Centrum Onkologii - Instytutu im. Marii Skłodowskiej-Curie w latach 1980-2005. Chore te stanowity 3,5\% wszystkich (96 276) chorych leczonych $w$ tym okresie z powodu raka piersi.

W tabeli I przedstawiono charakterystykę kliniczną i patologiczną omawianej grupy 220 chorych leczonych z powodu C-ILC.

Wiek chorych wahał się od 34 do 86 lat i wynosił średnio 59 lat (wartość mediany: 58 lat); większość z nich $(122 / 220-55,5 \%)$ była po menopauzie. Czas trwania objawów chorobowych (obecność guza w piersi) wahał się od 3 do 35 miesięcy i średnio wynosił 5 miesięcy. W 30 (13,6\%) przypadkach nowotwór w piersi został wykryty w trakcie badań profilaktycznych.

$\mathrm{U}$ wszystkich chorych zaawansowanie nowotworu ocenione zostało według klasyfikacji TNM obowiązujących w danym okresie, jednak na potrzeby prezentowanej analizy, na podstawie danych pochodzących z posiadanej dokumentacji medycznej, dokonano ponownej oceny stopnia zaawansowania zgodnie z obowiązującą klasyfikacją TNM [55].

W klinicznej ocenie stopnia zaawansowania według klasyfikacji TNM dominował II stopien (118 chorych - 52,7\%), natomiast po mikroskopowej ocenie preparatu operacyjnego najczęściej stwierdzano - w odniesieniu do pT — guza o wymiarze poniżej $5 \mathrm{~cm}$ (u 172 chorych - 77,2\%), a w odniesieniu do stanu węzłów chłonnych $(\mathrm{pN})$ dominowała cecha pNO (u 121 chorych - 55\%). Analiza immunohistochemiczna wykazała obecność ekspresji receptorów estrogenowego (ER) u 178 chorych (80,9\%) i progesteronowego (PgR) u 160 chorych (72,7\%), natomiast w 77 przypadkach (35\%) nie stwierdzono nadekspresji białkaHER-2/neu.

$\mathrm{U}$ wszystkich chorych pierwotne leczenie polegało na przeprowadzeniu radykalnego zabiegu chirurgicznego. U $189(85,9 \%)$ wykonano radykalne odjęcie piersi, w tym u $18(8,2 \%)$ metodą Halsteda (chore leczone w latach 1980-1985), u 132 (60,0\%) metodą Pateya, a u 39 (17,7\%) metodą Maddena. U 31 (14,1\%) chorych wykonano tumorektomię z limfadenektomią pachową z następową radioterapią (leczone w latach 1999-2005). Pooperacyjna radioterapia przeprowadzona została u 141 chorych (64,1\%), w tym u 31 chorych po zabiegu oszczędzającym, gdzie stanowiła integralną część takiego postępowania.W tym przypadku, przy zastosowaniu techniki wiązek tangencjalnych, napromieniano całą pierś, podając dawkę 50 Gy w 25 frakcjach w czasie 5 tygodni wiązką fotonową, a następnie podwyższano dawkę o $10 \mathrm{~Gy}$ na obszar loży po usuniętym guzie (tzw. boost), stosując wiązkę elektronową. U pozostałych $110(50,0 \%)$ chorych pooperacyjna radioterapia stosowana była po mastektomii (chore te stanowiły $58,2 \%$ ) w przypadku obecności przerzutów w węzłach chłonnych pachowych i/lub gdy wielkość guza w piersi przekraczała $5 \mathrm{~cm}$ średnicy. $W$ tej sytuacji obszar
Tabela I. Charakterystyka kliniczna i patologiczna grupy 220 chorych na klasyczną postać zrazikowego raka piersi (C-ILC)

\begin{tabular}{lcc}
\hline Czynnik & $\begin{array}{c}\text { Liczba } \\
\text { chorych }\end{array}$ & $\%$ \\
\hline Wiek: & & \\
$\quad$ 60 lat & 115 & 52,3 \\
$\quad$ 60 lat & 105 & 47,7 \\
Menopauza: & & \\
$\quad$ przed & 70 & 31,8 \\
w trakcie & 28 & 12,7 \\
po & 122 & 55,5
\end{tabular}

Czas trwania objawów chorobowych:

$\begin{array}{lcc}\text { S 6 miesięcy } & 126 & 57,3 \\ \text { > 6 miesięcy } & 64 & 29,1 \\ \text { guz wykryty w badaniach profilaktycznych } & 30 & 13,6 \\ \text { opień zaawansowania (wg TNM 2012): } & & \\ \text { I } & 33 & 15,0 \\ \text { II A } & 50 & 22,7 \\ \text { II B } & 68 & 30,0 \\ \text { III A } & 69 & 31,3\end{array}$

Wielkość guza (pT):

$\begin{array}{lcc}<3 \mathrm{~cm} & 57 & 25,9 \\ 3-5 \mathrm{~cm} & 115 & 52,3 \\ >5 \mathrm{~cm} & 48 & 21,8\end{array}$

Stan węzłów chłonnych pachowych (pN): pNO

$\mathrm{pN}+1-3$

$\mathrm{pN}+\geq 4$

Wieloogniskowość raka w piersi:

tak

nie

Ekspresja receptora estrogenowego:

obecna

nieobecna

brak danych

Ekspresja receptora progesteronowego:

$\begin{array}{lcc}\text { obecna } & 160 & 72,7 \\ \text { nieobecna } & 17 & 7,7 \\ \text { brak danych } & 43 & 19,6\end{array}$

Ekspresja białka c-erb-B2 (HER-2/neu):

$\begin{array}{lcc}\text { obecna } & 3 & 1,4 \\ \text { nieobecna } & 77 & 35,0 \\ \text { brak danych } & 140 & 63,6\end{array}$

Zakres leczenia chirurgicznego:

$\begin{array}{lll}\text { radykalne odjęcie piersi } & 189 & 85,9\end{array}$

leczenie oszczędzające pierśs $\quad 31 \quad 14,1$

Rozwój raka w drugiej piersi w trakcie 10-letniej obserwacji:

\begin{tabular}{rcc} 
tak & 19 & 8,6 \\
nie & 201 & 91,4 \\
\hline Razem & 220 & 100,0 \\
\hline
\end{tabular}


napromieniany obejmował ścianę klatki piersiowej wraz z blizną pooperacyjną oraz regionalne węzły chłonne (pachowe, przymostkowe, podobojczykowe, nadobojczykowe). Radioterapię realizowano z użyciem wiązki fotonowej (kobalt 60 lub fotony 6-9MV) oraz wiązki elektronowej, padając dawkę 50 Gy w 25 frakcjach w czasie 5 tygodni.

Systemowe leczenie uzupełniające polegało na stosowaniu hormonoterapii lub chemioterapii. U 120 (54,5\%) chorych zastosowano wyłącznie hormonoterapię tamoksyfenem. Spośród 99 (45,0\%) chorych, u których stwierdzono przerzuty do węzłów chłonnych pachowych (pN+), u 35 zastosowano samodzielną chemioterapię (według schematu CMF - endoksan, 5-fluorouracyl, metotreksat), a u pozostałych 64 - chemio-i hormonoterapię.

Jako kryterium skuteczności leczenia przyjęto 10-letnie przeżycie bez objawów nowotworu, licząc od daty wykonania zabiegu operacyjnego. Wszystkie chore obserwowano przynajmniej przez 10 lat, o ile wcześniej nie nastąpił zgon. Średni czas obserwacji wyniósł 12 lat (zakres: 10-25 lat).

W trakcie 10-letniej obserwacji u $19(8,6 \%)$ chorych stwierdzono rozwój raka w drugiej piersi; w 11 przypadkach raka był to ponownie C-ILC, natomiast w 8 - IDC. Raka drugiej piersi rozpoznano po leczeniu w: 5 roku ( 6 chorych), 7 roku (6 chorych), 8 roku (4 chorych) i 9 roku (3 chorych).

Prawdopodobieństwo przeżycia oszacowano metodą Kaplana-Meiera, a różnice w wynikach oceniono testem log-rank wg Peto i wsp. Ocena wpływu wybranych czynników na wyniki leczenia dokonana została z wykorzystaniem modelu proporcjonalnego hazardu Coxa. We wszystkich metodach statystycznych przyjęto poziom znamienności statystycznej dla $p \leq 0,05$.

\section{Wyniki}

W badanej grupie 220 chorych na C-ILC bez objawów nowotworu 10 lat przeżyło 143, tzn. 65,0\% chorych.

Rycina 1 przedstawia krzywą przeżycia bez objawów nowotworu, a w tabeli ll zestawiono wyniki analizy wpływu wybranych czynników na wyniki leczenia w badanej grupie 220 chorych na C-ILC.

Wyniki jednocechowej analizy wykazały, że istotnymi statystycznie czynnikami prognostycznymi w odniesieniu do przeżycia bez objawów nowotworu były: stopień zaawansowania nowotworu (według TNM), wielkość guza $\mathrm{w}$ piersi oceniona $\mathrm{w}$ materiale operacyjnym (pT) oraz stan mikroskopowy węzłów chłonnych pachowych (pN). Istotnie większe odsetki 10-letnich przeżyć bez objawów nowotworu stwierdzono w przypadku I-II stopnia vs III stopnia zaawansowania, gdy pT nie przekraczał $5 \mathrm{~cm}$ oraz gdy nie stwierdzono przerzutów w węzłach chłonnych (pN0).

W analizie wielocechowej przeprowadzonej z wykorzystaniem modelu Coxa jedynym niezależnym czynnikiem prognostycznym dla 10-letnich przeżyć bezobjawowych okazał się mikroskopowy stan węzłów chłonnych pacho-

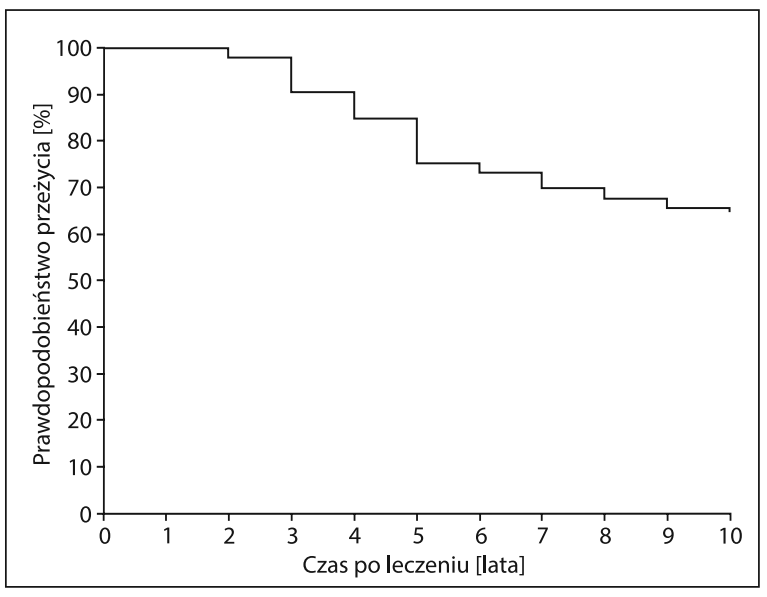

Rycina 1. Krzywa prawdopodobieństwa przeżycia bez objawów nowotworu w grupie 220 chorych na C-ILC

wych (ryzyko względne: 6,28 dla 95\% przedziału ufności: $1,95-8,13$ i wartości $p=0,003$ ).

Rycina 2 przedstawia krzywe przeżycia w zależności od stanu węzłów chłonnych.

Ocena zależności wyników leczenia od zakresu zabiegu operacyjnego wykazała, że leczenie oszczędzające pierś jest równie skuteczne jak metody radykalnego odjęcia piersi, oczywiście przy zastosowaniu właściwej kwalifikacji chorych do takiego postępowania.

W tabeli III zestawiono wyniki obserwacji chorych prowadzonej po zakończeniu leczenia.

Spośród wszystkich 220 chorych 16 (7,3\%) chorych zmarło bez objawów nowotworu (odpowiednio: 12 chorych pomiędzy 3 i 5 rokiem po leczeniu, a 4 chore w 7 i 8 roku) z powodu: chorób sercowo-naczyniowych (12 chorych), wypadku drogowego (2 chore), samobójstwa (1 chora), stwardnienia bocznego zanikowego (1 chora).

Rak piersi był przyczyną zgonu u $61(27,7 \%)$ chorych, w tym u 49 (22,3\%) był to C-ILC, a u pozostałych 12 (5,4\%) — IDC zlokalizowany w drugiej piersi. U wszystkich chorych, które zmarły z powodu C-ILC, przyczyną niepowodzenia leczenia był rozwój przerzutów do narządów odległych, z czego u 2 chorych towarzyszyła temu wznowa lokoregionalna. Średni czas rozwoju przerzutów wynosił 64 miesiące po leczeniu (zakres: 3-165 miesiące, mediana: 63 miesiące).

W tabeli IV zestawiono częstość lokalizacji przerzutów odległych.

Oprócz typowych dla raka piersi lokalizacji przerzutów do kości, płuc, wątroby i mózgu (łącznie 49,2\%) zwracają uwagę nietypowe lokalizacje, takie jak: żołądek, jelito cienkie, jelito grube, odbytnica, otrzewna, jajniki, trzon macicy, skóra.

\section{Dyskusja}

\section{Charakterystyka patokliniczna C-ILC}

Przeprowadzona analiza grupy 220 chorych leczonych w latach 1980-2005 w Krakowskim Oddziale Centrum On- 
Tabela II. Wyniki analizy wpływu czynników populacyjnych, klinicznych i mikroskopowych oraz zakresu leczenia chirurgicznego na wyniki leczenia

\begin{tabular}{|c|c|c|c|c|}
\hline \multirow[t]{2}{*}{ Czynniki } & \multirow[t]{2}{*}{ Liczba chorych leczonych } & \multicolumn{2}{|c|}{$\begin{array}{c}\text { 10-letnie przeżycie bez } \\
\text { objawów }\end{array}$} & \multirow[t]{2}{*}{$\begin{array}{c}\mathrm{p} \\
\text { (test log-rank) }\end{array}$} \\
\hline & & Liczba chorych & (\%) & \\
\hline \multicolumn{5}{|l|}{ Wiek: } \\
\hline$\leq 60$ lat & 115 & 74 & 64,3 & \multirow{2}{*}{ N.S. } \\
\hline$>60$ lat & 105 & 69 & 65,7 & \\
\hline \multicolumn{5}{|l|}{ Menopauza: } \\
\hline przed & 70 & 46 & 65,7 & \multirow{2}{*}{ N.S. } \\
\hline w trakcie i po & 150 & 97 & 64,7 & \\
\hline \multicolumn{5}{|l|}{ Czas trwania objawów chorobowych: } \\
\hline$\leq 6$ miesięcy & 126 & 82 & 65,1 & \multirow{3}{*}{ N.S. } \\
\hline$>6$ miesięcy & 64 & 41 & 64,1 & \\
\hline guz wykryty w badaniach profilaktycznych & 30 & 20 & 66,7 & \\
\hline \multicolumn{5}{|l|}{ Stopień zaawansowania (wg TNM 2012): } \\
\hline$I+\|$ & 151 & 112 & 74,2 & \multirow{2}{*}{$<0,05$} \\
\hline IIIA & 69 & 31 & 44,9 & \\
\hline \multicolumn{5}{|l|}{ Wielkość guza (pT): } \\
\hline$\leq 5 \mathrm{~cm}$ & 172 & 124 & 72,1 & \multirow{2}{*}{$<0,05$} \\
\hline$>5 \mathrm{~cm}$ & 48 & 19 & 39,6 & \\
\hline \multicolumn{5}{|l|}{ Stan węzłów chłonnych pachowych (pN): } \\
\hline pNO & 121 & 97 & 80,8 & \multirow{2}{*}{$<0,05$} \\
\hline $\mathrm{pN}+$ & 99 & 46 & 46,5 & \\
\hline \multicolumn{5}{|l|}{ Wieloogniskowość raka w piersi: } \\
\hline tak & 14 & 9 & 64,3 & \multirow{2}{*}{ N.S. } \\
\hline nie & 206 & 134 & 65,0 & \\
\hline \multicolumn{5}{|l|}{ Ekspresja receptora estrogenowego: } \\
\hline obecna & 178 & 117 & 65,7 & \multirow{3}{*}{ N.S. } \\
\hline nieobecna & 2 & 0 & - & \\
\hline brak danych & 40 & 26 & 65,0 & \\
\hline \multicolumn{5}{|l|}{ Ekspresja receptora progesteronowego: } \\
\hline obecna & 160 & 106 & 66,3 & \multirow{3}{*}{ N.S. } \\
\hline nieobecna & 17 & 9 & 52,9 & \\
\hline brak danych & 43 & 28 & 65,1 & \\
\hline \multicolumn{5}{|l|}{ Ekspresja białka c-erb-B2 (HER-2/neu): } \\
\hline obecna & 3 & 0 & - & \multirow{3}{*}{ N.S. } \\
\hline nieobecna & 77 & 51 & 66,2 & \\
\hline brak danych & 140 & 92 & 65,7 & \\
\hline \multicolumn{5}{|l|}{ Zakres leczenia chirurgicznego: } \\
\hline radykalne odjęcie piersi & 189 & 120 & 63,5 & \multirow{3}{*}{ N.S. } \\
\hline leczenie oszczędzające & 31 & 23 & 74,2 & \\
\hline Razem & 220 & 143 & 65,0 & \\
\hline
\end{tabular}

N.S. - non significant (różnice statystycznie nieistotne, $p>0,05$ )

kologii pozwoliła na znalezienie charakterystycznych cech populacyjnych, klinicznych i histopatologicznych, do których miedzy innymi należą: średni wiek chorych (59 lat), dominacja zaawansowania klinicznego w stopniu I-II (67,7\% chorych) z guzem w piersi, którego średnica nie przekracza
$5 \mathrm{~cm}$ (78,2\% chorych), brak przerzutów w węzłach chłonnych pachowych (pN0 u 55\% chorych), liczba zajętych węzłów większa niż 3 dotycząca zaledwie $10 \%$ chorych, wysoki odsetek chorych z ekspresją receptorów: estrogenowego $(80,9 \%)$ i progesteronowego $(72,7 \%)$ i niska częstość eks- 


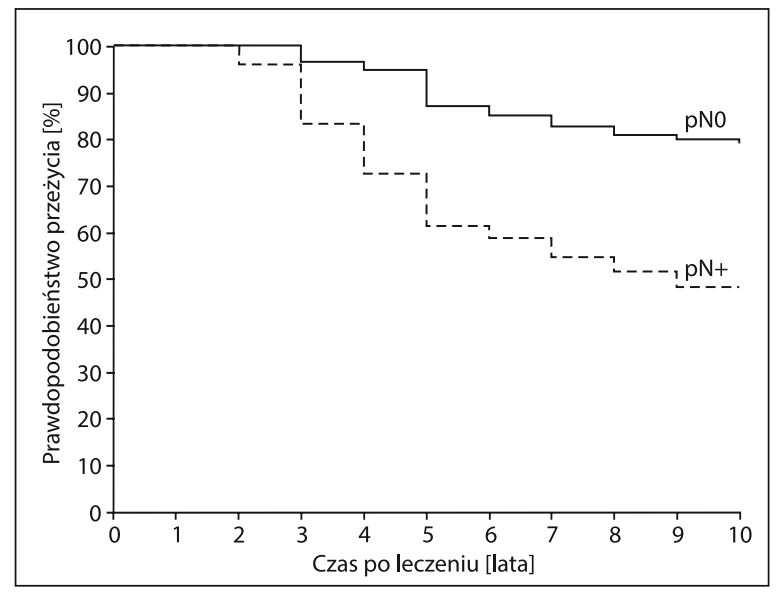

Rycina 2. Krzywe prawdopodobieństwa przeżycia bez objawów nowotworu w zależności od stanu węzłów chłonnych (pN)

Tabela III. Obserwacja po leczeniu w badanej grupie chorych

\begin{tabular}{lcc}
\hline Zdarzenia & Liczba chorych & $\%$ \\
\hline Przeżycie 10 lat bez objawów nowotworu & 143 & 65,0 \\
Zgony & 77 & 35,0 \\
Przyczyny zgonu: & & \\
$\quad$ rak piersi: & 49 & 22,3 \\
$\quad$ C-ILC & 12 & 5,4 \\
$\quad$ IDC (w drugiej piersi) & 16 & 7,3 \\
$\quad$ inne przyczyny & 220 & 100,0 \\
\hline Razem
\end{tabular}

C-ILC — klasyczna postać naciekającego zrazikowego raka piersi IDC — naciekający przewodowy rak piersi

Tabela IV. Lokalizacja przerzutów odległych C-ILC w grupie 55 chorych (zmarłe z powodu C-ILC)

\begin{tabular}{lcc}
\hline Lokalizacja przerzutów & Liczba chorych* & $\%$ \\
\hline Kości & 16 & 29,1 \\
Płuca & 5 & 9,1 \\
Wątroba & 3 & 5,5 \\
Mózg & 3 & 5,5 \\
Żołądek & 5 & 9,1 \\
Jelito cienkie & 1 & 1,8 \\
Jelito grube & 5 & 9,1 \\
Odbytnica & 3 & 5,5 \\
Otrzewna & 5 & 9,1 \\
Jajniki & 5 & 9,1 \\
Trzon macicy & 2 & 3,5 \\
Skóra & 1 & 1,8 \\
Szpik kostny & 1 & 1,8 \\
\hline Razem & $55^{*}$ & 100,0 \\
\hline
\end{tabular}

*U 3 chorych stwierdzono synchroniczne przerzuty w 2 lub 3 lokalizacjach presji HER2/neu (3,7\%). Ponadto stwierdzono obecność zmian wieloogniskowych w piersi $(6,4 \%)$ oraz rozwój raka w drugiej piersi $(8,6 \%)$.

Podobne cechy przedstawiane są u chorych na ILC powszechnie w piśmiennictwie, chociaż w różnym nasileniu i konfiguracji $[2,4,6-8,11,13,23,24,26,28,33,35-37,40,42,51$, $55,56]$, w tym również u chorych na C-ILC [10, 41, 51, 55, 57].

W piśmiennictwie autorzy szczególnie zwracają uwagę na te cechy C-ILC, które odróżniają go od innych postaci raka piersi, w szczególności od IDC:

a) istnieje zgodność co do tego, że C-ILC jest postacią mikroskopową raka piersi, w której szczególnie często stwierdza się wieloogniskowość zmian nowotworowych, a częstość tego zjawiska ocenia się na 4,5\% do 31\% [1, 6, $11,24,25,28,38,56] ;$ w badanej grupie - 6,4\%,

b) większość autorów wykazuje większe ryzyko rozwoju raka w drugiej piersi u chorych na C-ILC w porównaniu z chorymi na IDC, jednak wskaźnik ten waha się dość istotnie, od kilku do ponad $20 \%[1,6,11-13,23-25,28$, 38, 41, 56, 58-61]; w badanej grupie 8,6\%,

c) część autorów sugeruje, że ryzyko przerzutów do węzłów chłonnych pachowych jest niższe u chorych na ILC $[24,37,42,56]$, jednak analiza znacząco dużych badań wykazuje, że jest ono w zasadzie takie samo jak u chorych na IDC $[4,12,26,36,44-46,57,59,61]$; w badanej grupie chorych pN+ było $45 \%$,

d) zdecydowanie przeważa opinia, że ILC częściej niż IDC wykazuje ekspresję receptorów hormonalnych i znacznie rzadziej ekspresję białka c-erb-B2 (HER2/neu) [2, $6,7,24,35,62,63$; ; potwierdzają to dane zestawione w tabeli V.

Obserwacje własne oraz dane z piśmiennictwa potwierdzają, że ILC (w tym również C-ILC) charakteryzuje wysoki odsetek chorych z ekspresją receptorów estrogenowych (71\%-99\%) i receptorów progesteronowych (51\%-90\%) oraz niski $(0,0 \%-14 \%)$ - z ekspresją c-erbB2 (HER2/neu). Według danych WHO 80\%-95\% chorych na ILC wykazuje ekspresję receptorów estrogenowych, zaś 60-70\% receptorów progesteronowych; nadekspresja receptora HER-2 jest rzadka. Autorzy podkreślają, że szczególnie wysoki, sięgający 100 odsetek chorych na C-ILC wykazuje ekspresję receptorów estrogenowych [55].

\section{Ocena skuteczności leczenia chorych na C-ILC}

Przeprowadzone badania wykazały skuteczność pierwotnego leczenia operacyjnego z ewentualną uzupełniającą radioterapią i/lub leczeniem systemowym (chemioi/lub hormonoterapią); 10 lat bez objawów nowotworu przeżyło $65 \%$. W tabeli VI przedstawiono wyniki leczenia chorych na ILC według wybranych, dostępnych danych z piśmiennictwa.

Jak wynika z tabeli Vl, wyniki własne są porównywalne z danymi z piśmiennictwa. Analiza zależności wyników le- 
Tabela V. Częstość występowania ekspresji receptorów hormonalnych (estrogenowego — ER i progesteronowego — PgR) oraz białka e-erb B2 (HER-2/ /neu) u chorych na ILC

\begin{tabular}{|c|c|c|c|}
\hline \multirow[t]{2}{*}{ Publikacja (pozycja piśmiennictwa) } & \multicolumn{3}{|c|}{ Częstość ekspresji } \\
\hline & ER & $\mathrm{PgR}$ & e-erb B2 (HER-2/neu) \\
\hline Sastre-Garau i wsp. 1996 [24] & 79,0 & 63,0 & b.d. \\
\hline Mathieu i wsp. 2004 [66] & 91,0 & 71,0 & 5,3 \\
\hline Molland i wsp. 2004 [61] & 92,0 & 82,0 & b.d. \\
\hline Moran i wsp. 2009 [35] & 71,0 & 60,0 & 14,0 \\
\hline Mise i wsp. 2010 [70] & $82,0^{*}$ & $78,0^{*}$ & $3,0^{*}$ \\
\hline Jung i wsp. 2010 [2] & 90,4 & 71,1 & 2,5 \\
\hline Anwar i wsp. 2010 [60] & 85,8 & b.d. & b.d. \\
\hline Silberfein i wsp. 2010 [38] & 87,2 & 60,7 & 8,5 \\
\hline Wasif i wsp. 2010 [4] & 93,1 & 76,2 & b.d. \\
\hline Fortunato i wsp. 2012 [56] & b.d. & 98,0 & b.d. \\
\hline Skotnicki i wsp. 2012 [7] & $98,2^{*}$ & $87,5^{*}$ & $0,0^{*}$ \\
\hline Biglia i wsp. 2013 [6] & 98,3 & 89,0 & b.d. \\
\hline Narbe i wsp. 2014 [62] & 88,0 & 51,0 & 2,0 \\
\hline Brouckaert i wsp. 2014 [41] & $99,0^{*}$ & $90,3^{*}$ & $1,7^{*}$ \\
\hline Loibl i wsp. 2014 [40] & b.d. & 88,5 & 13,3 \\
\hline Fernández i wsp. 2014 [36] & 72,0 & 58,0 & b.d. \\
\hline Wang i wsp. 2014 [67] & 90,3 & 73,8 & b.d. \\
\hline Skotnicki i wsp. prezentowane wyniki własne 2015 & 98,8 & 90,1 & 3,8 \\
\hline
\end{tabular}

*Wyłącznie C-ILC; b.d. — brak danych; ER — receptor estrogenowy; PgR - receptor progesteronowy

Tabela VI. Wyniki leczenia (przeżycia bez objawów nowotworu) chorych na ILC

\begin{tabular}{|c|c|c|}
\hline \multirow[t]{2}{*}{ Publikacja (pozycja piśmiennictwa) } & \multicolumn{2}{|c|}{$\begin{array}{l}\text { Przeżycia bezobjawowe } \\
\text { (DFS) }\end{array}$} \\
\hline & 5-letnie & 10-letnie \\
\hline Silverstein i wsp. 1994 [59] & \multicolumn{2}{|c|}{ 74\% (7-letnie) } \\
\hline Sastre-Garau i wsp. 1996 [24] & $73 \%$ & $55 \%$ \\
\hline Cocquyt i wsp. 2003 [64] & $80,8 \%$ & b.d. \\
\hline Mersin i wsp. 2003 [65] & $71 \%$ & b.d. \\
\hline Mathieu i wsp. 2004 [66] & $94 \%$ & $58 \%$ \\
\hline Molland i wsp. 2004 [61] & \multicolumn{2}{|c|}{ 87\% (4-letnie) } \\
\hline Arpino i wsp. 2004 [68] & $80 \%$ & $65 \%$ \\
\hline Cristofanilli i wsp. 2005 [57] & $87 \%$ & b.d. \\
\hline Tubiana-Hulin i wsp. 2006 [42] & $76,5 \%$ & b.d. \\
\hline Pestalozzi i wsp. 2008 [44] & $70 \%$ & $49 \%$ \\
\hline Rakha i wsp. 2008 [37] & $72 \%$ & $60 \%$ \\
\hline Dian i wsp. 2009 [69] & b.d. & $64 \%$ \\
\hline Jung i wsp. 2010 [2] & $91,7 \%$ & b.d. \\
\hline lorfida i wsp. 2012 [10] & $90 \%$ & $74 \%$ \\
\hline Fortunato i wsp. 2012 [56] & $86 \%$ & b.d. \\
\hline Biglia i wsp. 2013 [6] & $89 \%$ & b.d. \\
\hline $\begin{array}{l}\text { Skotnicki i wsp. } \\
\text { prezentowane wyniki własne } 2015\end{array}$ & b.d. & $65 \%$ \\
\hline
\end{tabular}

*DFS - disease-free survival; b.d. — brak danych czenia chorych badanej grupy potwierdziła, że przy przestrzeganiu odpowiednich wskazań alternatywą radykalnej mastektomii może być leczenie oszczędzające pierś, zwłaszcza jeżeli uzyskuje się margines operacyjny wolny od nacieku raka i skojarzy leczenie chirurgiczne $z$ adiuwantową radioterapią, co jest zgodne $z$ aktualnymi danymi piśmiennictwa [3, 6, 8, 28, 35, 49, 56, 59-65].

Niezależnym, niekorzystnym czynnikiem prognostycznym w badanej grupie była mikroskopowa obecność przerzutów C-ILC w węzłach chłonnych pachowych, co jest również całkowicie zgodne z doniesieniami innych autorów $[4,6$, $10-12,24,33,35,36,40,50,56,58,61,65-69]$.

\section{Analiza niepowodzeń leczenia}

Spośród 220 chorych badanej grupy 49 (22,3\%) zmarło z powodu C-ILC; u wszystkich tych chorych przyczyną niepowodzenia leczenia było wystąpienie przerzutów odległych. Oprócz typowych dla przewodowego raka piersi lokalizacji przerzutów do płuc, wątroby, kości i mózgu u prawie połowy chorych z uogólnionym procesem nowotworowym stwierdzono nietypowe lokalizacje, takie jak żołądek, jelito cienkie, jelito grube, odbytnica, otrzewna, jajniki, trzon macicy, skóra. Zjawisko to znajduje potwierdzenie w danych z piśmiennictwa, gdzie podkreśla się, że ILC zdecydowanie częściej aniżeli IDC przerzutuje do przewodu pokarmowego, narządu rodnego, otrzewnej czy opon mózgowych [1, 5, 6, $11,24,26,34,36,41,56,68,70]$. 
Część autorów sugeruje, że specyficzna, odmienna od innych postaci mikroskopowych raka piersi lokalizacja przerzutów odległych u chorych na ILC związana jest z brakiem ekspresji kadheryny E i zaburzeniami adhezji komórek [71, 72]. Jednak nie tylko nietypowe lokalizacje przerzutów ILC mogą być zaskakujące dla klinicysty, ale i czas ich wystąpienia, często po kilkunastu latach od pierwotnego leczenia [73]. Rozpoznanie przerzutu z ILC może często stwarzać trudności, należy więc wykorzystać wszelkie możliwości diagnostyczne, między innymi obrazowe, biopsję podejrzanej zmiany oraz badania immunohistochemicznie. Co do tych ostatnich, należy pamiętać, że wiele badań wykazuje różnice stanu biomarkerów (receptory hormonalne, HER-2/neu) pomiędzy pierwotnym guzem a jego przerzutami $[70,74]$. Są również sytuacje, że rak rozwijający się pierwotnie w innej lokalizacji może naśladować ILC, a nawet w bardzo rzadkich sytuacjach dawać przerzuty do piersi i naśladować pierwotnego ILC [73].W leczeniu przerzutów C-ILC konieczne jest więc ścisła współpraca chirurga, patologa, radiologa, chemio- i radioterapeuty, by zapobiec błędnym diagnozom, a co za tym idzie — błędnej terapii.

\section{Wnioski}

Analiza własnego materiału oraz danych z piśmiennictwa pozwala na sformułowanie następujących wniosków:

1) obraz kliniczny C-ILC charakteryzuje: wieloogniskowość nowotworu w piersi (6,4\%), ryzyko rozwoju raka w drugiej piersi (8,6\%), wysoki odsetek chorych wykazujących ekspresję receptorów hormonalnych (ER - 80,9\%, PgR - 72,7\%) i niski (3,8\%) - wykazujących ekspresję białka c-erb-B2 (HER-2/neu), a także tendencja do rozwoju przerzutów odległych w nietypowej dla raka piersi lokalizacji (przewód pokarmowy, narząd rodny, opony mózgowe),

2) wyniki leczenia chorych na C-ILC są dobre; $65 \%$ chorych przeżywa 10 lat bez objawów raka; przy zachowaniu właściwej kwalifikacji alternatywą radykalnego odjęcia piersi może być leczenie oszczędzające, zwłaszcza jeżeli uzyska się margines operacyjny wolny od nacieku raka i zastosuje adiuwantową radioterapię. Niezależnym, niekorzystnym czynnikiem prognostycznym jest obecność przerzutów C-ILC w węzłach chłonnych pachowych.

\section{Konflikt interesów: nie zgłoszono}

\author{
Prof. nadzw. dr hab. med. Beata Sas-Korczyńska \\ Klinika Onkologil \\ Centrum Onkologii — Instytut im. Marii Skłodowskiej-Curie \\ Oddział w Krakowie \\ ul. Garncarska 11, 31-115 Kraków \\ e-mail:z5korczy@cyf-kr.edu.pl
}

Otrzymano: 19 czerwca $2015 \mathrm{r}$.

Przyjęto do druku: 4 sierpnia 2015 r.

\section{Piśmiennictwo}

1. Arrangoiz R, Papavasiliou P, Dushkin H i wsp. Case report and literature review: Metastatic lobular carcinoma of the breast an unusual presentation. Int J Surg Case Rep 2011; 2: 301-305.

2. Jung SY, Jeong J, Shin SH i wsp. The invasive lobular carcinoma as a prototype luminal $A$ breast cancer: a retrospective cohort study. BMC Cancer 2010; 10: 664.

3. Skotnicki P, Ryś J, Jakubowicz J i wsp. Kontrowersje dotyczące metod i wyników leczenia chorych na naciekającego zrazikowego raka piersi. Nowotwory J Oncol 2008, 58: 533-536.

4. Wasif N, Maggard MA, Ko CY i wsp. Invasive lobular vs. ductal breast cancer: a stage-matched comparison of outcomes. Ann Surg Oncol 2010; 17: 1862-1869.

5. Bose R. A neu view of invasive lobular breast cancer. Clin Cancer Res 2013; 19: 3331-3333.

6. Biglia N, Maggiorotto F, Liberale V i wsp. Clinical-pathologic features, long term-outcome and surgical treatment in a large series of patients with invasive lobular carcinoma (ILC) and invasive ductal carcinoma (IDC). Eur J Surg Oncol 2013; 39: 455-460.

7. Skotnicki P, Ryś J, Blecharz P i wsp. Invasive lobular carcinoma of the breast: cytometric and immunohistochemical characteristics of 96 cases. Pol J Pathol 2012; 63: 112-120.

8. Sakr RA, Poulet B, Kaufman GJ i wsp. Clear margins for invasive lobular carcinoma: a surgical challenge. Eur J Surg Oncol 2011; 37: 350-356.

9. Foote FW, Stewart FW. Lobular carcinoma in situ: A rare form of mammary cancer. Am J Pathol 1941; 17: 491-496.

10. Iorfida $M$, Maiorano $E$, Orvieto $E$ i wsp. Invasive lobular breast cancer subtypes and outcome. Breast Cancer Res Treat 2012;133:713-723.

11. DiCostanzo D, Rosen PP, Gareen I i wsp. Prognosis in infiltrating lobular carcinoma. An analysis of "classical" and variant tumors. Am J Surg Pathol 1990; 14: 12-23.

12. Jeziorski A. Co wiemy o raku zrazikowym piersi? Wsp Onkol 2004; 8: 269-275.

13. du Toit RS, Locker AP, Ellis IO i wsp. Invasive lobular carcinomas of the breast--the prognosis of histopathological subtypes. Br J Cancer 1989; 60: 605-609.

14. Skotnicki P, Ryś J, Jakubowicz J i wsp. Czy odmiana mikroskopowa inwazyjnego zrazikowego raka piersi ma znaczenie prognostyczne? Onkol Radiother 2008; 2: 16-21.

15. Shousha S, Backhous CM, Alaghband-Zadeh J i wsp. Alveolar variant of invasive lobular carcinoma of the breast. A tumor rich in estrogen receptors. Am J Clin Pathol 1986; 85: 1-5.

16. Green I, McCormick B, Cranor M i wsp. A comparative study of pure tubular and tubulolobular carcinoma of the breast. Am J Surg Pathol 1997; 21: 653-657

17. Buchanan $\mathrm{CL}$, Flynn LW, Murray MP i wsp. Is pleomorphic lobular carcinoma really a distinct clinical entity? J Surg Oncol 2008; 98: 314-317.

18. Gupta A, Sharma N, Jha AK i wsp. Pleomorphic variant of lobular carcinoma breast: a rare case report with review of the literature. $J$ Cancer Res Ther 2012; 8: 320-322.

19. Jung SP, Lee SK, Kim Si wsp. Invasive pleomorphic lobular carcinoma of the breast: clinicopathologic characteristics and prognosis compared with invasive ductal carcinoma. J Breast Cancer 2012; 15: 313-319.

20. Butler D, Rosa M. Pleomorphic lobular carcinoma of the breast: a morphologically and clinically distinct variant of lobular carcinoma. Arch Pathol Lab Med 2013; 137: 1688-1692.

21. Tan PH, Harada O, Thike AA i wsp. Histiocytoid breast carcinoma: an enigmatic lobular entity. J Clin Pathol 2011; 64: 654-659.

22. Eltorky M, Hall JC, Osborne PT i wsp. Signet-ring cell variant of invasive lobular carcinoma of the breast. A clinicopathologic study of 11 cases. Arch Pathol Lab Med 1994; 118: 245-248.

23. Martinez V, Azzopardi JG. Invasive lobular carcinoma of the breast: incidence and variants. Histopathology 1979; 3: 467-488.

24. Sastre-Garau X, Jouve $M$, Asselain B i wsp. Infiltrating lobular carcinoma of the breast. Clinicopathologic analysis of 975 cases with reference to data on conservative therapy and metastatic patterns. Cancer 1996; 77: 113-120.

25. Cserni G. Reproducibility of a diagnosis of invasive lobular carcinoma. J Surg Oncol 1999; 70: 217-221.

26. Yeatman TJ, Cantor AB, Smith TJ i wsp. Tumor biology of infiltrating lobular carcinoma. Implications for management. Ann Surg 1995; 222: 549-559; discussion 559-561.

27. Reis-Filho JS, Simpson PT, Jones Ci iwsp. Pleomorphic lobular carcinoma of the breast: role of comprehensive molecular pathology in characterization of an entity. J Pathol 2005; 207: 1-13. 
28. Tavassoli FA, Devilee P. World Health Organization classification of tumours pathology and genetics of tumours of the breast and female genital organs. Lyon: IARC Press; 2003; 23-25.

29. Palacios J, Sarrió D, García-Macias MC i wsp. Frequent E-cadherin gene inactivation by loss of heterozygosity in pleomorphic lobular carcinoma of the breast. Mod Pathol 2003; 16: 674-678.

30. Pai K, Baliga P, Shrestha BL. E-cadherin expression: a diagnostic utility for differentiating breast carcinomas with ductal and lobular morphologies. J Clin Diagn Res 2013; 7: 840-844.

31. Rakha EA, Patel A, Powe DG i wsp. Clinical and biological significance of E-cadherin protein expression in invasive lobular carcinoma of the breast. Am J Surg Pathol 2010; 34: 1472-1479.

32. Singhai R, Patil VW, Jaiswal SR i wsp. E-Cadherin as a diagnostic biomarker in breast cancer. N Am J Med Sci 2011; 3: 227-233.

33. Lips EH, Mukhtar RA, Yau C i wsp. Lobular histology and response to neoadjuvant chemotherapy in invasive breast cancer. Breast Cancer Res Treat 2012; 136: 35-43.

34. Sobinsky JD, Willson TD, Podbielski FJ i wsp. Unusual metastatic patterns of invasive lobular carcinoma of the breast. Case Rep Oncol Med 2013, article ID 986517

35. Moran MS, Yang Q, Haffty BG. The Yale University experience of early-stage invasive lobular carcinoma (ILC) and invasive ductal carcinoma (IDC) treated with breast conservation treatment (BCT): analysis of clinical-pathologic features, long-term outcomes, and molecular expression of $\mathrm{COX}-2, \mathrm{BCl}-2$, and $\mathrm{p} 53$ as a function of histology. Breast J 2009; 15: 571-578.

36. Fernández B, Paish EC, Green AR i wsp. Lymph-node metastases in invasive lobular carcinoma are different from those in ductal carcinoma of the breast. J Clin Pathol 2011; 64: 995-1000.

37. Rakha EA, El-Sayed ME, Powe DG i wsp. Invasive lobular carcinoma of the breast: response to hormonal therapy and outcomes. Eur J Cancer 2008; 44: 73-83.

38. Silberfein EJ, Hunt KK, Broglio K i wsp. Clinicopathologic factors associated with involved margins after breast-conserving surgery for invasive lobular carcinoma. Clin Breast Cancer 2010; 10: 52-58.

39. Sikora MJ, Cooper KL, Bahreini A i wsp. Invasive lobular carcinoma cell lines are characterized by unique estrogen-mediated gene expression patterns and altered tamoxifen response. Cancer Res 2014; 74: 1463-1474

40. Loibl S, Volz C, Mau C i wsp. Response and prognosis after neoadjuvant chemotherapy in 1,051 patients with infiltrating lobular breast carcinoma. Breast Cancer Res Treat 2014; 144: 153-162.

41. Brouckaert O, Laenen A, Smeets A i wsp. Prognostic implications of lobular breast cancer histology: new insights from a single hospital cross-sectional study and SEER data. Breast 2014; 23: 371-377.

42. Tubiana-Hulin M, Stevens D, Lasry Si wsp. Response to neoadjuvant chemotherapy in lobular and ductal breast carcinomas: a retrospective study on 860 patients from one institution. Ann Oncol 2006; 17: 1228-1233.

43. Orvieto E, Maiorano E, Bottiglieri L i wsp. Clinicopathologic characteristics of invasive lobular carcinoma of the breast: results of an analysis of 530 cases from a single institution. Cancer 2008; 113: 1511-1520.

44. Pestalozzi BC, Zahrieh D, Mallon E i wsp. Distinct clinical and prognostic features of infiltrating lobular carcinoma of the breast: combined results of 15 International Breast Cancer Study Group clinical trials. J Clin Oncol 2008; 26: 3006-3014.

45. Korhonen T, Kuukasjärvi T, Huhtala H i wsp. The impact of lobular and ductal breast cancer histology on the metastatic behavior and long term survival of breast cancer patients. Breast 2013; 22: 1119-1124.

46. Jayasinghe UW, Bilous AM, Boyages J. Is survival from infiltrating lobular carcinoma of the breast different from that of infiltrating ductal carcinoma? Breast J 2007; 13: 479-485.

47. VoTN, Meric-Bernstam F, Yi M i wsp. Outcomes of breast-conservation therapy for invasive lobular carcinoma are equivalent to those for invasive ductal carcinoma. Am J Surg 2006; 192: 552-555.

48. van den Broek N, van der Sangen MJ, van de Poll-Franse LV i wsp. Margin status and the risk of local recurrence after breast-conserving treatment of lobular breast cancer. Breast Cancer Res Treat 2007; 105: 63-68.

49. Jobsen JJ, Riemersma S, van der Palen J i wsp. The impact of margin status in breast-conserving therapy for lobular carcinoma is age related. Eur J Surg Oncol 2010; 36: 176-181.

50. Bollet MA, Savignoni A, Pierga JY i wsp. High rates of breast conservation for large ductal and lobular invasive carcinomas combining multimodality strategies. Br J Cancer 2008; 98: 734-741.
51. Purushotham A, Pinder S, Cariati Mi wsp. Neoadjuvant chemotherapy: not the best option in estrogen receptor-positive, HER2-negative, invasive classical lobular carcinoma of the breast? J Clin Oncol 2010; 28: 3552-3554.

52. Jeziorski A. Czy chore z inwazyjnym rakiem piersi mają gorsze rokowanie? Onkol Pol 2003; 3: 125-133.

53. Lee JH, Park S, Park HS, Park BW. Clinicopathological features of infiltrating lobular carcinomas comparing with infiltrating ductal carcinomas: a case control study. World J Surg Oncol 2010; 8: 34.

54. Colleoni M, Rotmensz N, Maisonneuve P i wsp. Outcome of special types of luminal breast cancer. Ann Oncol 2012; 23: 1428-1436.

55. Lakhani SR, Ellis IO, Schmitt SJ i wsp. (eds.) WHO classification of tumours of the breast. TNM classifaction of tumours of the breast. Lyon: International Agency for Research on Cancer, 2012.

56. Fortunato L, Mascaro A, Poccia I i wsp. Lobular breast cancer: same survival and local control compared with ductal cancer, but should both be treated the same way? analysis of an institutional database over a 10-year period. Ann Surg Oncol 2012; 19: 1107-1114.

57. Cristofanilli M, Gonzalez-Angulo A, Sneige N i wsp. Invasive lobular carcinoma classic type: response to primary chemotherapy and survival outcomes. J Clin Oncol 2005; 23: 41-48.

58. Hussien M, Lioe TF, Finnegan J i wsp. Surgical treatment for invasive lobular carcinoma of the breast. Breast 2003; 12: 23-35.

59. Silverstein MJ, Lewinsky BS, Waisman JR i wsp. Infiltrating lobular carcinoma. Is it different from infiltrating duct carcinoma? Cancer 1994; 73: 1673-1677.

60. Anwar IF, Down SK, Rizvi S i wsp. Invasive lobular carcinoma of the breast: should this be regarded as a chronic disease? Int J Surg 2010; 8: 346-352.

61. Molland JG, Donnellan M, Janu NC i wsp. Infiltrating lobular carcinoma - a comparison of diagnosis, management and outcome with infiltrating duct carcinoma. Breast 2004; 13: 389-396.

62. Narbe U, Bendahl PO, Grabau D i wsp. Invasive lobular carcinoma of the breast: long-term prognostic value of Ki67 and histological grade, alone and in combination with estrogen receptor. Springerplus 2014; 3:70.

63. http://www.springerplus.com/content/3/1/70.

64. Cocquyt VF, Blondeel PN, Depypere HT i wsp. Different responses to preoperative chemotherapy for invasive lobular and invasive ductal breast carcinoma. Eur J Surg Oncol 2003; 29: 361-367.

65. Mersin $\mathrm{H}$, Yildirim $\mathrm{E}$, Gülben $\mathrm{K}$ i wsp. Is invasive lobular carcinoma different from invasive ductal carcinoma? Eur J Surg Oncol 2003; 29: 390-395.

66. Mathieu MC, Rouzier R, Llombart-Cussac A i wsp. The poor responsiveness of infiltrating lobular breast carcinomas to neoadjuvant chemotherapy can be explained by their biological profile. Eur J Cancer 2004; 40: 342-351.

67. Wang J, Mittendorf EA, Sahin AA i wsp. Outcomes of sentinel lymph node dissection alone vs. axillary lymph node dissection in early stage invasive lobular carcinoma: a retrospective study of the surveillance, epidemiology and end results (SEER) database. PLoS One 2014; 9: e89778. doi: 10.1371/journal.pone.0089778.

68. Arpino G, Bardou VJ, Clark GM i wsp. Infiltrating lobular carcinoma of the breast: tumor characteristics and clinical outcome. Breast Cancer Res 2004; 6: 149.

69. Dian D, Herold H, Mylonas I i wsp. Survival analysis between patients with invasive ductal and invasive lobular breast cancer. Arch Gynecol Obstet 2009; 279: 23-28.

70. Mise I, Vucić M, Maricević I i wsp. Histologic subtypes of invasive lobular carcinoma in correlation with tumor status and hormone receptors. Acta Clin Croat 2010; 49: 275-281.

71. Bertucci F, Orsetti B, Nègre V i wsp. Lobular and ductal carcinomas of the breast have distinct genomic and expression profiles. Oncogene 2008; 27: 5359-5372.

72. Berx G, Cleton-Jansen AM, Strumane K i wsp. E-cadherin is inactivated in a majority of invasive human lobular breast cancers by truncation mutations throughout its extracellular domain. Oncogene 1996; 13: 1919-1925.

73. Mallon E, Varga Z. Relapse of invasive lobular carcinoma. Breast Dis 2008-2009; 30: 53-56.

74. Broom RJ, Tang PA, Simmons C i wsp. Changes in estrogen receptor progesterone receptor and Her-2/neu status with time: discordance rates between primary and metastatic breast cancer. Anticancer Res 2009; 29: 1557-1562. 